Dossiê Crise do Congresso 


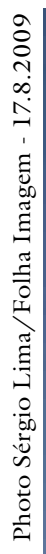

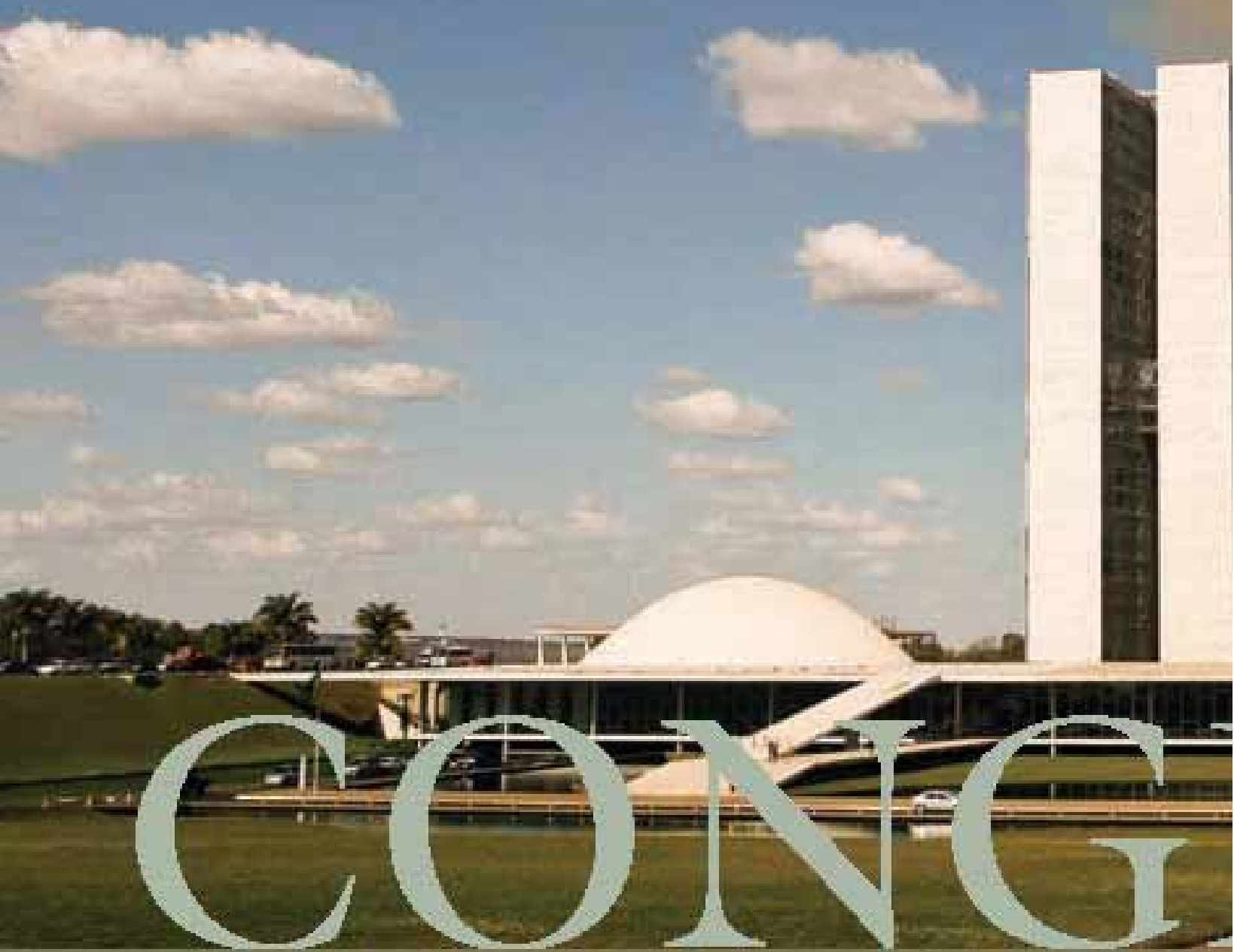

The editorial board of ESTUDOS AVANCSADOS does not hold itself responsible for the opinions expressed by the collaborators of the Crisis in the Congress Dossier. 


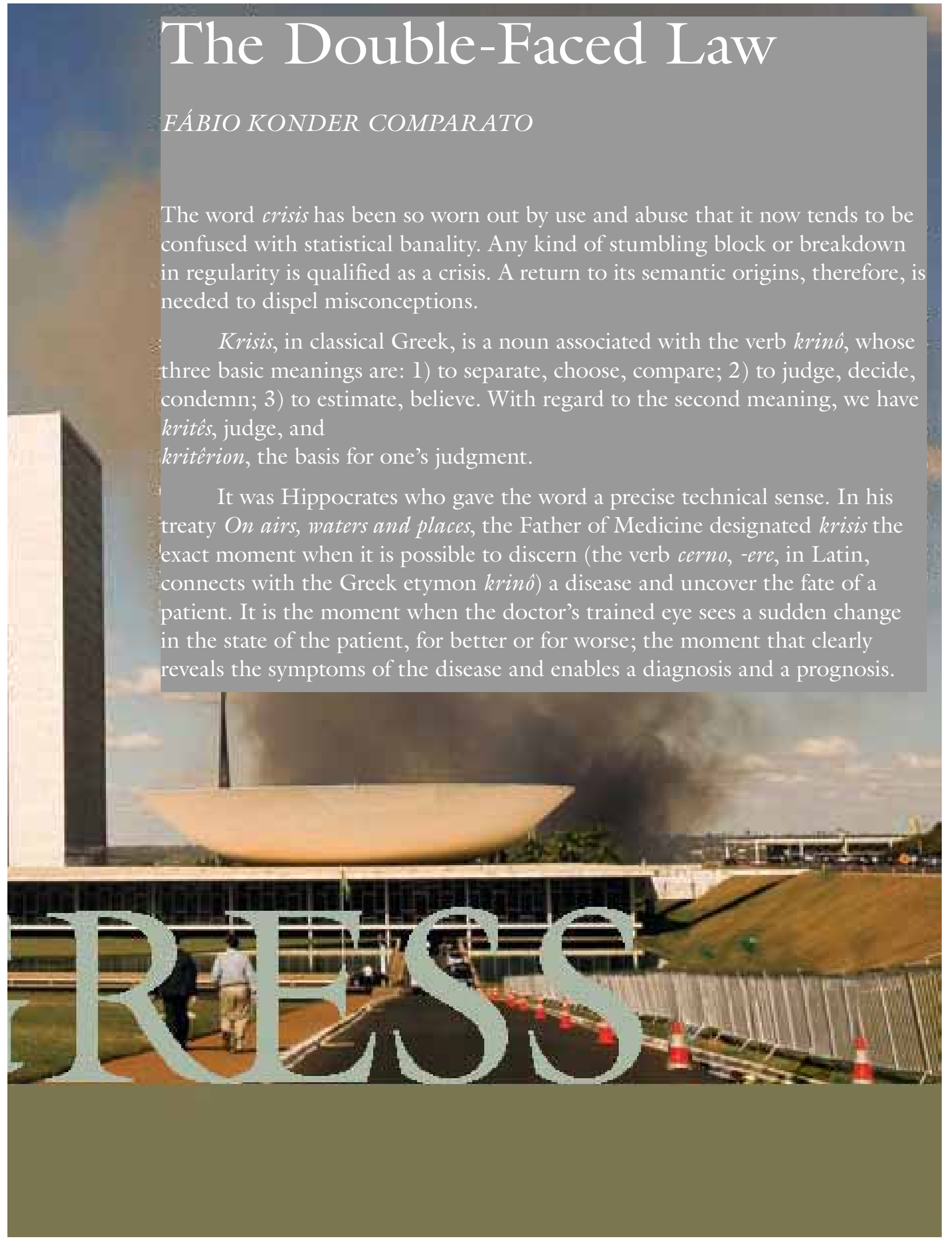


In face of the proliferation of scandals in the Brazilian Congress, we are naturally led to ask whether we have reached a decisive historical moment in which it is possible to discern the etiology of our political malaise and predict its outcome.

Having absolutely no wish to answer this question, I confine myself here to attempt a historical explanation for the evils that chronically afflict us.

\section{The Duplicity of the Brazilian Legal Systems}

In "The Mirror," a short story by Machado de Assis, the narrator assures his amazed listeners that each of us has two souls. An external one, which we display to others and by which we judge ourselves from the outside in; and an internal one, rarely exposed to the outside eyes, with which we judge the world and ourselves from the inside out.

I believe something similar happens with regard to the Brazilian legal corpus. In every country, there is an explicit law, but there is also an implicit law, hidden from prying eyes, that regulates the facts concerning what might be called the intimate life of the nation.

Historical examples of this legal dualism abound. I will recall here just one. Soon after the French Revolution, the aristocrat Joseph de Maistre stated that France was then divided into two countries: the legal one and the real one. For him, the radical changes made in the political regime after 1789 were confined to the surface of things. The country remained monarchical, as it had always been, and split into the traditional three estates: the clergy, the nobility and the people.

To be sure, if things are properly analyzed from outside academic dogmatism, we cannot but recognize that, unlike what the $18^{\text {th }}$ century American and French revolutionaries thought, a Constitution is not merely a document for the political organization of a country. Underlying this form - or, if you will, on the reverse side of it - lies another reality, equally normative, but without an official seal of approval. Just like the politeia of the city-states of classical Greece, it resembles an unwritten, but unquestionably valid Constitution. It is established by traditional practices and customs, the prevailing values of society and the complex field of private powers, intertwined with public jurisdiction.

If we cast our eyes on Brazil, we will recognize, without much analytical effort, that the Constitutions here promulgated, when seen through the external soul referred to by the narrator of "The Mirror," are invariably clothed in gala costumes and proudly displayed to foreigners as evidence of our civilized character. They resemble liturgical garments, worn by doctors and magistrates in official ceremonies of worship. For daily household use, however, we naturally prefer to wear simpler and more comfortable clothes.

Because of this institutional duplicity, corresponding to the two faces of our national character, we have managed to live quite smoothly, throughout our history, with a series of "unfortunate misunderstandings," in the famous expression of Sérgio Buarque de Holanda. People at large were conspicuously 
absent from all of them, however, and most of the conflicts that emerged among the ruling classes were solved by agreement or a conciliation of opposing parties.

Our Independence did not stem from a revolt of the Brazilian people against the king of Portugal, but from a rebellion of the Portuguese people against the king in Brazil. In Grito do Ipiranga [The Call at the Ipiranga], the celebrated painting by Pedro Américo [depicting the alleged moment of the proclamation of Independence], the artist unwittingly symbolized the Brazilian people in the figure of a coachman by the roadside, barefooted and bare-chested, contemplating the heroic scene in fascination, as if asking himself what was the meaning of all that pomp and circumstance.

Soon after the dissolution of the Constituent Assembly in 1823, the emperor declared he was determined to grant the nation a Constitution "duplicately more liberal" than the one being drafted. The Constitutional Charter, a document imposed on the Brazilian people from above, completely omitted any reference, however perfunctory, to slavery. Clearly, great care was taken to establish a "manor house liberalism," so to speak, to which, for reasons of fundamental decency, the "nameless vile populace" mentioned by Camões should not have access.

The military revolt in Campo de Santana on November 15, 1889, which the people gawked at as if bestialized, in Aristides Lobo's famous expression, did not aim to abolish the Monarchy, but simply to unseat the liberal ministry of Afonso Celso de Assis Figueiredo [Viscount of Ouro Preto]. It did not cross the mind of any of the intellectual leaders of the movement, all of them positivists, to oppose this anti-republican centuries-old practice. Already in the early $17^{\text {th }}$ century friar Vicente do Salvador[lamented that "not one man in this land is a republican, or cares for or looks after the common good, but only their private assets".

The Revolution of 1930 was triggered by a desire to end the distortions of the representative system, rigged elections being a common practice of local chieftains. After not many years, the revolution had transfigured into a dictatorship with broad popular acceptance.

The peaceful transition from authoritarianism to constitutional rule, at the end of both Getúlio Vargas' Estado Novo and the two decades of military regime forty years later, was assured by the enactment of amnesty laws to political opponents. This was the explicit law. Underlying it, however, was the implicit law that amnesty would be extended to public officials and their accomplices responsible for tortures, summary executions, the disappearance of political foes and other unspeakable abuses.

Therefore, what we have seen in all these historical episodes was not the replacement of a juridical regime by another, but an amalgam of the new and the old, of abrogated law and abrogative law. The former, although invited to leave the front stage, did not withdraw from the juridical theater: it was simply consigned to the background, a still unforgotten character, waiting to emerge on the scene at a timely moment. 
Apparently, two-faced Janus, the Roman god of gates and doors, has been an effective guardian angel of our ruling classes. When the explicit law does not go against their interests, they exalt it as the only legitimate and enforceable law. However, as soon as the slightest contradiction arises between constitutional or legal precepts and the power that these classes effectively detain and exercise in society, the communication doors of explicit law open automatically, allowing the admission of other, previously hidden rulings that legitimize and validate the traditional status dominii. In some cases, as we'll see regarding the deliverance of slaves, a more flexible and generous common law was developed side by side with the strictness of explicit law.

Incidentally, that is why capitalism was so quick to grow deep roots amidst us. Because one of the main features of the "spirit" of capitalism, which Max Weber did not point out in his famous essay ${ }^{1}$, is its chameleonic ability to conceal real facts with the mantle of ideology. The evocation of individual freedom is always used to justify the submission of workers, consumers and of the State itself to the dominant power of businesses in the marketplace. The principle of equality under law hides the systematic domination of the poor by the rich, of consumers by producers, of ignorant and unwise users by the utilities. Napoleon was right - not the Corsican, but the dictator pig in George Orwell's Animal farm - when he warned that "all animals are equal, but some animals are more equal than others."

To uncover the origins of the dual character of Brazilian law, we must undoubtedly go back to the time when the Portuguese colonized these lands.

The written law - the Ordinances of the Kingdom, in addition to all the later laws, provisions and permits - came from the mother country, that is, reeked of imported rules, alien to our milieu. These rules commanded respect, but not necessarily obedience. The maxim that was disseminated all over Hispanic America also prevailed here: las Ordenanzas del Rey Nuestro Señor se acatán pero no se cumplen ["the Ordinances of Our Lord the King are heeded but not complied with"].

To the establishment, year after year, of this veritable system of trompe l'oeil, as the French would say, whereby the official law was artificially highlighted to create the illusion that it corresponded to reality, much contributed the officials sent from Portugal, who, upon arriving here, often joined the families of wealthy local masters through godfathering or even marriage - or, alternatively, acquired land and went themselves into the crop exporting business ${ }^{2}$.

Under such conditions, it is easier to understand how great were the pressures to provide the metropolitan-originated laws a less literal interpretation more in tune with the economic interests of those who had settled here. In a letter to D. João VI, dated April 4, 1654, the priest Antonio Vieira complained (p. 173):

Everything in this state, the inordinate greed of those who govern it has destroyed; yet, even after razing it, they cease not the means to consume it even further. [The states of] Maranhão and Pará are Portugal's La Rochelle, a conquest to be conquered, a land where Your Majesty is cited, but not obeyed. 
After the Independence, two examples serve perfectly to illustrate what I have just stated: the slavery of Africans and African descendants, and the reaction of our ruling groups to the idea of establishing a democracy in our midst.

\section{The Two Faces of the Slavery}

The Constitution of 1824 declared that "whipping, torture, hot iron branding and all other cruel punishments are hereby abolished" (art. 179, XIX).

In 1830, however, a Criminal Code was enacted that included chain gangs as a means of punishment, as described in article 44 , subjecting "culprits to walk with clamps and irons on their feet, together or separately, and be employed in the public works of the province where they committed their offense, at the Government's disposal. "Needless to say that this kind of punishment, considered humane by the 1830 legislators, actually applied only to slaves.

There was more. Despite the explicit constitutional prohibition, captives continued to branded with hot iron and regularly flogged until right before the Abolition - more precisely, until the law of October 16, 1886. Article 60 of the same Criminal Code established a maximum of fifty whippings a day, but the legal provision was never respected. It was common for the poor devils to endure two hundred lashes daily. That legislation was only enacted by the Chamber of Deputies because, not long before, two of four slaves condemned to three hundred lashes by a jury trial in Paraiba do Sul died.

Not to mention mutilating punishments, such as having all of one's teeth broken, the fingers chopped off or the breasts pierced.

Interestingly, this harsh reality was never recognized by our ill-named elite. Writing in 1866 a treatise on slavery in Brazil, Perdigão Malheiro was keen to stress the "the admittedly compassionate and humanitarian disposition of the Brazilians," our "proverbially kind” temperament. Gilberto Freyre (1947, p. 108 ff.), in turn, backed by the testimony of foreigners who visited our country in the early $19^{\text {th }}$ century, argued that hereabouts slavery was more benign than that practiced in the English colonies.

Although constantly soft-pedaled, it is undeniable that an unofficial law of slavery never ceased to exist. A good example is the fact that the slave trade continued for many and many years, in a situation of blatant illegality.

An ordinance dated January 26, 1818, issued by the Portuguese king while in Brazil, in compliance with the treaty established with England, banned this infamous trade under the penalty of forfeiting the slaves, who should be "immediately released." After Brazil's independence, the country signed a new convention with England in 1826, by which any trafficking carried out more than three years after the exchange of ratifications would considered piracy. During the Regency [1831-1840], under pressure by the English, the ban was reiterated by law on November 7, 1831.

This intricate legal apparatus, however, remained a dead letter, because it had been enacted only "for the English to see," as a popular Brazilian expression 
has it. According to the great black lawyer Luiz Gama, who had himself been sold into slavery by his father when he was only ten,

shipments were unloaded in public view at selected points of the Brazil coastline, near fortresses in full sight of the police, without reserve or mystery; without any shame or embarrassment, the Africans were carried through the roads, sold in villages and farms, and baptized as slaves by the clerics, by the conscientious parish priests!... (in Menucci, p. 171)

The same Luiz Gama tells of an episode that occurred in the mid-1850s and is a perfect illustration of the widely accepted dubiousness of Brazilian law in this area.

In those days, a provincial farmer came to São Paulo, bringing letters of recommendation from political chieftains, in pursuit of two runaway slaves, who, being uncultured and unable to speak the country's mother tongue, had been seized by a block inspector and granted freedom, in accordance with the Eusébio de Queiroz Act of $1850 .^{3}$

Having received no assistance from the local authorities, the farmer sought out the Court, where he conferred with the minister of Justice, the respected senator and counselor Nabuco de Araújo. Shortly thereafter, the provincial president received a "confidential note" from the minister, in which His Excellency acknowledged that the negroes had been "properly apprehended and declared free by the chief of police, being Africans illegally imported into the Empire."

The minister continued:

However, it should be taken into account that this incident, given the country's present circumstances, is very serious and dangerous; it alarms the farmers, can upset their credit, become the cause of incalculable loss, and disrupt public order. The law was strictly enforced; there are, however, great interests of a higher order that cannot be overlooked and should preferably be considered.

If these negroes were to disappear from their current placement, with no prejudice to the good reputation of the authorities and without any liability of their part, what harm will result? (in Menucci, p. 184-5)

And that was indeed what happened, "with no prejudice to the good reputation of the authorities and without any liability of their part..."

In an insightful study on the manumission of slaves during the imperial period, Manuela Carneiro da Cunha (1986, p.123 ff.) leads us on the slippery slope of out-and-out ambiguity. All over the country, a tradition had consolidated of compulsory liberating slaves through the payment, either by the slaves themselves or by other parties, of the conventional price of redemption. Yet, there was never a formal, legal recognition of the captives' entitlement to forced manumission. In his 1866 treatise on slavery, Perdigão Malheiro ( $\$ 93 \mathrm{ff}$.) discusses the theoretical constitutionality of a law that recognized compulsory 
manumission through the payment to slave masters of the cash redemption value of a slave, and makes it clear Brazil did not have at the time any law in this regard. It was only with the Law of the Free Womb, dated September 28, 1871, that the right of slaves to have their own savings, and thus acquire their own freedom, was finally admitted.

For Manuela Carneiro da Cunha, two juridical systems coexisted in Brazilian society in the $19^{\text {th }}$ century: one based on written laws, the other on unwritten laws "pertaining to particular relations of dependency and power." It was possible for both systems to coexist because their scopes of application were basically different: "to the free poor, essentially, the law; to the powerful, their slaves and their clients, the custom law." Cunha concludes: "[the law] is also the external face, the international but not necessarily false face of a system that, domestically, differs."

A better example could not be found of the typically Bovaristic quality of our ruling classes. Like Flaubert's tragic character, they are always trying to flee our awkward and backward reality, which we find shameful, and sublimate in the imagination, for the whole country and for each one of us in particular, an identity and the ideal conditions of life that we pretend to have, but which are actually totally foreign to us.

In this regard, we are the perfect embodiment of Fernando Pessoa's "faker poet $^{4}$." We are so good at our act of faking that we actually think the ideal law that figures in our Constitution and Codes actually exists and is regularly obeyed.

Let us now examine a notable case of social schizophrenia: the notion of democracy.

\section{The "Unfortunate Misunderstanding" of Democracy}

When we split from Portugal, the idea of popular sovereignty was considered anathema to our ruling classes.

In May 1811, in the pages of the Correio Braziliense newspaper, published in London, Hipólito José da Costa insisted on making an emphatic warning:

No one desires useful reforms more than us; but no one is more annoyed than us that these reforms are made by the people, because we know the vile consequences of this mode of reform; we want reforms, but by the government, and we urge the government to carry them out while there is still time, so as to avoid having them made by the people. (Barbosa Lima Sobrinho, 1977, p.79-80)

More than a century later, we find this statement being echoed by the then-president of the state of Minas Gerais, Antonio Carlos Ribeiro de Andrada, who warned at the end of the Old Republic [1889-1930]: "Let us make the revolution before the people themselves make it!"

In Fallas do trono... (1889, p.6), addressed to the members of the 1823 Constituent Assembly, Brazil's first emperor, D. Pedro I, referred with contempt to the country's enemies, entrenched "in democratic Portuguese courts." The 
monarch then stated he expected the Constitution-in-draft to place "inaccessible barriers to despotism, whether real or democratic" (ibid, p.16). Shortly thereafter, on July 19 of that year, feeling the wind of the people's (i.e., the municipalities') rebellion blowing, D. Pedro I issued a proclamation with a warning:

Some Chambers of the northern provinces wherein reigns the democratic spirit have so instructed their deputies. Democracy in Brazil! In our vast and great empire, this is absurd; and no less absurd is their intention of prescribing laws to those who should make them, threatening them with the loss or derogation of power, which had not been granted them nor was it their due to grant.

It is true that the movement that led to the abdication of D. Pedro I, on April 7, 1831, was an attempt to conciliate liberalism and democracy. Shortly after, however, the liberal leaders backtracked and returned things to their proper places. The recantation of Teófilo Ottoni was, in this aspect, paradigmatic. Excusing himself for his past liberal-democratic fancies, he stated that he had always sought "only peaceful democracy, a democracy of the middle classes, a clean-tie democracy, a democracy that rejects with equal disgust the despotism of the crowds and the tyranny of one" (in Bonavides \& Amaral, 1996, p.204-5).

After the end of the Paraguayan War, however, the idea of democracy, or rather of a democratic republic, quickly expunged of any subversive connotation, started to be invoked in public, not as a system of popular sovereignty, but as a justification for local-level political autonomy. Democracy and cognate expressions, such as democratic solidarity, democratic freedom, democratic principles and democratic guarantees, appear no less than 28 times in the Republican Manifesto of 1870. One of its topics is titled "The Democratic Truth." Significantly, however, not a word is said about the emancipation of slaves. It is known, by the way, that the leaders of the Republican Party opposed the Law of the Free Womb and only agreed to the abolition of slavery in 1887 , when it was almost an accomplished fact.

On June 27, 1878, a recently graduated lawyer, still unknown on the national scene, gave a speech at the Provincial Assembly of Bahia that might today be attributed to any member of the party that answers by the name Democrats. His name was Ruy Barbosa and he emphatically said that, "liberty and equality are diametrically opposed and go together only in the mouths of demagogues and tyrants." For him, the greatest threat to freedom was "tyranny [...] exercised by democracy against the individual." Stressing the importance of the "human molecule, the vigorous, educated and free individual," he said that political equality was always relative and dependent on "the inequality of social conditions" and the "inequality of natural abilities." The demand for equality for all, he concluded, was nothing more than a reflection of "corruption that comes from socialist error" (in Graham, 1990, p.184-5).

The country was living the onset of a movement for electoral reform and the abolition of indirect elections. The cabinet of prime minister João Lins 
Vieira Cansansão, viscount of Sinimbu, tried to have the reform enacted by the Chamber of Deputies, and, in order to reassure the ruling class of great landowners, proposed to purge the votes of illiterate and increase the census (i.e., the minimum annual income required for voters to register).

That was when José Bonifácio, the Younger, entered the scene. He was a professor at the Law School of São Paulo, and also a representative at the time, and is certainly the greatest parliamentary speaker the country has ever known. When he ascended the rostrum of the Assembly on the afternoon of April 28, 1879, the Chamber was bursting at the seams and the session had to be interrupted several times due to pressure from the huge audience that wished to enter the hall but was barred by security.

"Those who support this project," he said, to intense applause,

after half a century of constitutional government, repudiate those who sent us to this Chamber, those who are the true creators of national representation. Why? Because they cannot read, because they are illiterate! This discovery is truly bewildering! The sovereignty of grammarians is an error of political syntax [laughter and applause broke out on the floor]. Who is the subject of the clause? [Prolonged hilariousness]. Is it not the people? Who is the verb? Who is the patient? Ah, they have discovered a new rule: the subject is not required. They divide the people, get themselves elected by a small minority, and then enthusiastically cry out: "Here is the national representation!" (in Holanda, 1972, p.206)

Given the failure of the Sinimbu's cabinet in enacting the constitutional change needed to abolish indirect elections, the emperor appointed - José Antonio Saraiva, known as the Messiah of Ipojuca, as prime minister. Saraiva went straight to the point and concentrated his efforts of persuasion in rescuing the democratic idea. In a session of the Legislature in 1880, he said: "We enjoy complete democracy in Brazil. [...] We get along with everyone; we place the freedmen at our table and have more confidence in trustworthy freedmen than in many of our own citizens" (in Graham, 1990, p.32). ${ }^{5}$

He just left out that, once slavery was abolished, we would then create a perfectly egalitarian society. Actually, it did not take long for this to be officially proclaimed. In his Message to the Legislative Congress of São Paulo, 1912-1916, Francisco de Paula Rodrigues Alves, who had been president of Brazil from 1902 to 1906 , stated in passing, as if it were a self-evident truth: "Amongst us, in a regimen of bona fide democracy and complete absence of social classes..." (Egas, 1927).

Left in the shadows, however, were the inconvenient facts that in the last election of the Empire, in 1886, voters represented less than 1\% of the total population, and that in the election of Rodrigues Alves' successor to the presidency they barely accounted for $1.4 \%$. After all, despite the tiny electorate and the well-established practices of fraud, we had elections. Therefore, we 
had democracy. "A democracy Brazilian-style," as described by the general who ordered the arrest of the great lawyer Sobral Pinto in 1968, who replied: "General, I've only heard of turkey Brazilian-style."

To be sure, in seeking to justify the coup of 1964, the military leaders did not hesitate to declare themselves representatives of the Brazilian people and exercise constituent power on their behalf. ${ }^{6}$ Later, with Institutional Act No. 2 of October 27, 1965, Marshal Castello Branco and his ministers reproached the actions of "agitators of various breeds and elements of the deposed regime" who "threaten and challenge the revolutionary order itself precisely at the time when, alert to administrative problems, this order seeks to lead the people to the practice and discipline of the democratic exercise." "Democracy," the coup agents continued, "assumes freedom, but does not exclude accountability nor does it imply license to counter the political vocation of the Nation." What they meant by "political vocation" is unclear, but we are to assume they referred to the regime established by the coup of March of the previous year...

This rhetoric of unwavering defense of democracy to cover every sort of crime reached its peak with the infamous Institutional Act No. 5, of December 13, 1968, that opened the doors to State terrorism:

Considering that the Brazilian Revolution of March 31, 1964, in keeping with the Acts by which it was institutionalized, had foundations and purposes aimed at giving the country a regimen that, fulfilling the requirements of a juridical and political system, would ensure a genuine democratic order based on freedom, respect for human dignity etc.

If we turn our eyes to our present reality, we painfully recognize the permanence of that "unfortunate misunderstanding."

\section{The Persistence of the Democratic Misconception in the Current Political System}

The Federal Constitution of 1988 begins with the solemn declaration that "the Federative Republic of Brazil [...] is a democratic State of Law" in which "all power emanates from the people, who exercise it through elected representatives or directly, in the terms of this Constitution" (art. 1).

It so happens that this Constitution, as all the other ones that preceded it, was not ratified by the people. Those who drafted it titled themselves representatives of those from whom all power emanates. But those who were supposedly represented, and in whose name the Constitution was written, had absolutely no awareness, when electing them, that they were doing so for this greater purpose.

Worse still, the said representatives of the people, when drafting the Constitution - as had invariably happened in the past - claimed exclusively for themselves the power to change it without consulting those they represented. As I write these lines, the 1988 Constitution was amended (or mended) no less than 
63 times, a respectable average of more than three amendments per year. In none of these occasions did anyone remember to consult the sovereign people...

It goes without saying that, by attributing exclusively to themselves the power to change the Constitution - without even the slightest protest from anyone -, the parliamentarians became the true holders of sovereignty. By these means, therefore, we constitutionalized a dual political system: the actual, with a traditionally oligarchic nature; and the symbolic, of democratic expression.

Even a superficial analysis of other provisions of the 1988 Constitution confirms the existence of this double regime.

Article 14, for instance, states that popular sovereignty is to be exercised not only by direct election, but also through plebiscites and referendums, and by popular legislative initiatives. In article 49 , section XV, however, the Constitution includes, among the exclusive attributions of the National Congress, "to authorize referendums and call plebiscites."

According to the prevailing view, such acts of authorization and convocation are an essential condition for popular sovereignty to begin to manifest itself. In other words, the sovereign mandators cannot express their political will except with the consent of the mandataries. What an undeniably original creation of the Brazilian legal mind!

On November 18, 1998, Law No. 9709 was enacted to regulate the aforementioned article 14 of the Constitution. In a recent ruling, the Regional Electoral Tribunal (TRE) of the state of São Paulo, with regard to a plebiscite approved by the town council of Santo André, stated that this law was not applicable because it referred only to national plebiscites and referendums. In conclusion, without the supervision of the Electoral Justice, the plebiscite could not be held.

Quite logically then, according to this praetorian interpretation, we must accept one of the following three assumptions: either 1) the fundamental principle of popular sovereignty in the Constitution can only be applied through, and strictly comply with, legislative regulation, that is to say, the principle has purely programmatic value; or 2) the plebiscite is not a manifestation of popular sovereignty, but a concession that Congress makes to the people; or 3) cities - and states as well, it follows - are not component units of the Brazilian federation and, therefore, it should be understood that the sovereignty of the people exists only at the federal level.

Not to mention the fact that the people's representation in the Chamber of Deputies is determined by extremely disproportional voting ratios and by an electoral system structured on political parties that are now totally devoid of programmatic identity and public trust. And also not to mention the absurdity of giving the Senate greater political power than the Chamber of Deputies, since the Senate does not represent the unity of a sovereign people but rather the division of the Brazilian State into units formally deemed as equal despite enormous geoeconomic disparities. 
Given this, is it any wonder that Congress operates as an exclusive club, with its back to the people, whom it sovereignly ignores and neglects? Can it be a cause of surprise that the alienation of the political representatives has consolidated in their minds the belief that they are not liable to legal sanctions for their malfeasance, corruption and administrative improbity?

Some will counter the unsavory view of our political reality I have just presented by recalling the great advances in human rights championed by the 1988 Constitution. Undoubtedly, it would be foolish and unfair to deny the ethical progress stemming from the written law. But has the written law by any chance eliminated the traditional duplicity of our juridical system?

Let us consider a recent example. While the usurpatory deforcement of public lands in the Amazon is legitimized by means of a provisional measure, ${ }^{7}$ the peaceful occupation of unproductive estates by landless peasants, or the settlement of homeless families in empty urban lots, is systematically and violently suppressed by the police and denounced by the media as a serious disturbance of public order.

A similar scam has taken place with regard to the freedom of expression. In the past, newspapers and magazines were indispensable tools to ensure freedom of speech and control the acts of public officials. Thomas Jefferson even stated that, if having to choose between a political system without newspapers or newspapers in a politically unorganized society, he would unflinchingly prefer the latter. ${ }^{8}$ Yet, in the contemporary world, with rare exceptions, mass media has become the object of the oligopoly of capitalist enterprises, who detain undiluted power over public opinion. At present, the large social communication media denounces as censorship any legal attempt to regulate their programs,${ }^{9}$ but do not hesitate to censor or distort the news that go counter their own interests, sometimes even omitting any reference to people who criticize them.

Ignoring this reality that strikes the eye, the Federal Supreme Court has recently ruled that the press law enacted during the military regime (Law No. 5250 of 2.9.1967) was tacitly repealed by the 1988 Constitution. With this decision that supposedly stands up for freedom of speech, the Court eliminated any type of legal control over the activities of the media, making its power to pressure government agencies and influence public opinion irrevocable.

Can this state of affairs be changed?

\section{An Action Program}

As noted, the functional duality of Brazilian law has deep, traditional roots in a power system that is essentially oligarchic. Its endurance over centuries has forged a complex of customs and a social mindset that is unabashedly conservative.

Yet, the replacement of this juridical system by another is not simply a matter of normative change. Legal rules only become effective, i. e., only acquire strength or social vigor (according to the meaning of the Latin etymon vigeo, 
-ere), when imposed by an authority that was legitimately established and is legitimately maintained. When, in other words, they are effectively accepted by the people.

Everything revolves, therefore, around the dispensational status of sovereignty. Can we, in our country, replace the minority that has traditionally commanded the State with the people as a whole? And can we do it in a way that political power is exercised for the common good (res publica), not for special interests?

The answer to this question should stem from an analysis of power as a social phenomenon. As Max Weber (1985, p.28, $541 \mathrm{ff}$.) was able to show, power cannot be reduced simply to brute force, for it also comprises the voluntary obedience of those it submits. This obedience, as history has abundantly demonstrated, is based on an understanding of legitimacy, i. e., on the proper match between power relationships and the collective ethical sense. When the majority of society becomes aware of the irremediable injustice of the power system, the organization of power is already on its last legs.

This is, therefore, the action program that we, intellectuals, must be urgently carry out: it must become our priority to relentlessly denounce the absolute illegitimacy of the Brazilian political organization with regard to the great ethical principles.

\section{Conclusion}

In the funeral oration that Pericles delivered in memory of his kinsmen killed in the first year of the Peloponnesian War, he eulogized Athenian democracy. Among other things, he said that the public men of Athens had their private businesses to attend to, and those engaged in the pursuits of industry were also fair judges of public matters. He concluded: "Unlike other nations, we regard him who takes no part in politics not as unambitious or peaceful, but as a useless citizen" (Thucydides II, 40).

I would dare say that Pericles' assessment must be extended today. In our own time, anyone who stays aloof from politics to look after their private interests is a real menace to the public. Because it is precisely upon the indifference of the majority toward the common good of the people, on a national level, or of the commonwealth of all people, on a global level, that the modern system of voluntary servitude is built.

Dixi et salvavi animam meam. ${ }^{10}$ 


\section{Notes}

1 Die protestantische Ethik und der Geist der Kapitalismus, originally published in 1904/1905.

2 On this argument, see the invaluable study by Stuart B. Schwartz, Sovereignty and Society in Colonial Brazil; the High Court of Babia and its judges, 1609-1751, published here in a terrible translation titled Burocracia e sociedade no Brasil Colonial (Schwartz, 1979).

3 As is known, this law was enacted by the Assembly of the Empire five years after the British Parliament ratified the Aberdeen bill reiterating the qualifications of slave trade as piracy. The bill authorized the seizure of the slave ships and their human cargo, even in Brazilian waters, and the trial of the crew by the Admiralty Courts in London.

4 "The poet is a faker / Who's so good at his act / he even fakes the pain / of pain he feels in fact" [translated by Richard Zenith]

5 It should be noted that freedmen did not have full rights as citizens.

6 See the so-called Institutional Act No. 1, of April 9, 1964: "The Leaders of the victorious revolution, owing to the actions of the Armed Forces and the unequivocal support of the Nation, represent the People and exercise Constituent Power on their behalf."

7 Provisional measure no. 458, of 2009, became Law no. 11,952 of 6.25.2009.

8 Letter to Edward Carrington, sent from Paris on January 16, 1787, where Jefferson was ambassador: "The basis of our government being the opinion of the people, the very first object should be to keep that right; and where it left to me to decide whether we should have a government without newspapers, or newspapers without a government, I should not hesitate a moment to prefer the latter" (in Peterson, p.415).

9 To this day, more than twenty years after the enactment of the 1988 Constitution, there has been no regulation of articles 220 and 221 , which deal with the suitability of radio and television programs to the great republican and democratic values. Likewise, the concession, licensing and authorization of broadcasting services remain still subject to personal interests of politicians and business corporations.

10 "I have spoken and thus saved my soul."

\section{Bibliographic references}

BARBOSA LIMA SOBRINHO. Antologia do Correio Braziliense. S. 1.: Editora Cátedra MEC, 1977.

BONAV IDES, P.; AMARAL, R. Textos políticos da História do Brasil. Brasília: Senado Federal, 1996. v.2.

CUNHA, M. C. da. Sobre os silêncios da lei: lei costumeira e positiva nas alforrias de escravos no Brasil do século XIX. In: Antropologia do Brasil-mito, história, etnicidade. São Paulo: Brasiliense, Edusp, 1986. p.123 ff.

EGAS, E. (Org.) Galeria dos presidentes de São Paulo - Periodo Republicano 1889 - 1920. São Paulo: Publicação Official do Estado de S. Paulo, 1927. 
FALLAS DO TRONO, desde o anno de 1823 até o anno de 1889. Rio de Janeiro: Imprensa Nacional, 1889.

FREYRE, G. Interpretação do Brasil - Aspectos da formação social brasileira como processo de amalgamento de raças e culturas. Rio de Janeiro: Livraria José Olympio Editora, 1947. (Col. Documentos Brasileiros n.56).

GRAHAM, R. Patronage and Politics in Nineteenth-Century Brazil. S. 1.: Stanford University Press, 1990.

HOLANDA, S. B. de. História geral da civilização brasileira. São Paulo: Difusão Europeia do Livro, 1972. t.II, v.5.

MENUCCI, S. O precursor do abolicionismo no Brasil (Luiz Gama). São Paulo: Companhia Editora Nacional, no date (Col. Brasiliana, v.119).

PERDIGÃO MALHEIRO. A escravidão no Brasil. Ensaio histórico-jurídico-social. Rio de Janeiro: Typographia Nacional, no date. Part 3 - Africanos, Título I, Capítulo V, Título II, Capítulo III.

PETerSON, M. D. (Org.) The Portable Jefferson. S. 1.: Penguin Books, no date.

SCHWARTZ, S. B. Burocracia e sociedade no Brasil Colonial. São Paulo: Perspectiva, 1979.

VIEIRA, A. (Pe.) Obras escolhidas. Lisboa: Livraria Sá da Costa - Editora, no date. v.I, "Cartas (I)".

WEBER, M. Wirtschaft und Gesellschaft-Grundriss der verstehenden Soziologie. 5th ed. rev. Tübingen: J. C. B. Mohr, 1985.

ABSTR ACT - In every country, underlying the official law comprising the Constitution, statutes, rules issued by the Executive branch, and legal precedents, there is always another hidden order, based on the structure of the ruling powers within society and legitimized by the social mindset. This duplicity of legal systems has always existed in Brazil. In addition to the official law, which follows the operative standards of civilization of countries we consider to be culturally more advanced, there is also an unwritten law in force, aimed at protecting the interests of dominant social groups. This essay illustrates the twofold reality of Brazilian law with historical cases of slavery and democracy. In order to change this social structure, whose appearance does not reflect the actual reality, the author stresses the need for a broad and continual denunciation of its illegitimacy.

KEYWORDS: Law, Brazil, Slavery, Democracy. 
Fábio Konder Comparato is professor emeritus of the Law School of the University of São Paulo. He earned his doctorate in Law from the University of Paris and holds an honorary doctor's degree from the University of Coimbra. @ - fkcomparato@uol.com. br

Received on 9.14.2009 and accepted on 9.21.2009.

Translated by Carlos Malferrari. The original in Portuguese is available at http://www. scielo.br/scielo.php? script=sci_issuetoc\&pid=0103-401420090002\&lng=pt\&nrm=iso. 